\title{
Neonatally Induced Diabetes: Liver Glycogen Storage in Pregnant Rats
}

\author{
Isabela Lovizutto Iessi ${ }^{1}$, Aline Bueno ${ }^{1}$, Yuri Karen Sinzato ${ }^{1}$, Ana Paula Machado Spada ${ }^{1}$ \\ Marilza Vieira Cunha Rudge ${ }^{1}$, Maricê Thereza Correa Domingues Heubel $^{2}$ and Débora \\ Cristina Damasceno ${ }^{1 *}$ \\ ${ }^{1}$ Laboratório de Pesquisa Experimental de Ginecologia e Obstetrícia; Departamento de Ginecologia e Obstetrícia; \\ Universidade Estadual Paulista ; 18618-000; Botucatu - SP - Brasil. ${ }^{2}$ Laboratório de Biologia; Departamento de \\ Ciências Biológicas; Universidade Sagrado Coração; Bauru - SP - Brasil
}

\begin{abstract}
The aim of this sstudy was to evaluate the liver glycogen storage in pregnant rats presenting neonatal streptozotocin-induced diabetes and to establish a relation with glycemia and insulin levels. Wistar rats were divided in to two groups: 1) Mild Diabetes (STZ) - received streptozotocin (glycemia from 120 to $300 \mathrm{mg} / \mathrm{dL}$ ), 2) Control - received vehicle (glycemia below $120 \mathrm{mg} / \mathrm{dL}$ ). At days 0, 7, 14 and 21 of the pregnancy, body weight and glycemia were evaluated. At day 21 of the pregnancy, the rats were anesthetized for blood and liver collection so as to determine insulin and liver glycogen, which showed no changes in the STZ group as compared to the controls. In the STZ group, maternal weight gain were lower as compared to those in the control group. Significantly increased glycemia was observed at days 0 and 14 of the pregnancy in the STZ group. Therefore, neonatally induced diabetes in the rats did not cause metabolic changes that impaired insulin and liver glycogen relation in these rats.
\end{abstract}

Key words: pregnancy, rat, hyperglycemia, glycogen storage liver, mild diabetes, hyperglycemia

\section{INTRODUCTION}

Glycogen is one of the major storage polysaccharides of animal cells present in nature, and its synthesis is the process by which glucose is polymerized into glycogen. It accumulates in the cells in different amounts according to cell type, thus functioning as energy deposits. Glycogen is particularly abundant in the liver, where it constitutes $7 \%$ of that organ wet weight. Liver glycogen is degraded between the meals and keeps the level of blood glucose constant; at the same, it supplies such metabolite to other cells in the organism (Kasuga et al. 2003).
In pregnancy, maternal requirements of carbohydrates, proteins, and lipids increase due to deep physiological alterations and all the energy resources that are directed to the fetus, but without maternal damage. The main metabolic nutrients to the fetus are glucose and amino acids (Zaidise et al. 1999). Maternal glucose is considered to be an important energetic substrate for the fetal development, and fetal insulin acts as a growth factor (Calderon et al. 1999). The hormone is also responsible for stimulating the glycogenesis in the liver, and glycogen storage results in approximately $20 \%$ of the total ingestion of carbohydrates (Kasuga et al. 2003).

*Author for correspondence: damasceno@fmb.unesp.br 
Glycogenesis and glycogenolysis alterations may contribute to increase the postprandial hyperglycemia, leading to metabolic glycemic changes, such as diabetes (Hwang et al. 2005). Diabetes mellitus (DM) is a chronic disorder resulting from the lack of insulin production by the pancreatic $\beta$-cells or from a defect in insulin receptors in the target cells, which leads to the hyperglycemic metabolic disease. Several pathogenic processes are involved in the development of diabetes, from the autoimmune destruction of pancreatic $\beta$-cells to abnormalities that result in resistance to insulin action (ADA 2010).

DM conditions can be experimentally reproduced in the laboratory animals. In the rats with mild diabetes (glycemia between 120 and $300 \mathrm{mg} / \mathrm{dL}$ ), which reproduces type-2 DM or gestational DM, maternal hyperglycemia stimulates the fetal pancreas, leading to the hyperplasia and hyperactivity of pancreatic $\beta$-cells, resulting in fetal hyperinsulinemia, anabolism increase and, consequently, stimulation to the birth of macrosomic fetuses. In the adult phase, they develop excessive insulin resistance, and in the pregnancy, gestational diabetes. In severe diabetes, (glycemia > $300 \mathrm{mg} / \mathrm{dL}$ ), which would correspond to decompensated type-1 DM in human, glycemic levels also induce the hyperplasia of pancreatic $\beta$ cells and increase insulin secretion at an initial phase (Aerts and Van Assche 2006).

Many experimental studies have been performed in order to reproduce the diabetic state, evaluate its results and enhance the understanding of the physiopathological mechanisms involving that syndrome. For this reason, beta-cytotoxic drugs, such as streptozotocin (STZ), are used in the laboratory animals (Souza et al. 2010). Hence, this study aimed at evaluating hepatic glycogen storage in the pregnant rats with neonatal STZ-induced diabetes and establishing the relationship between glycemia and insulin levels.

\section{MATERIALS AND METHODS}

\section{Animals}

Virgin Wistar rats at reproductive age (three months), weighing from 180 to $200 \mathrm{~g}$, as well as adult males of the same species, weighing approximately $250 \mathrm{~g}$, were used. The animals were maintained under controlled conditions of temperature $\left(22 \pm 2^{\circ} \mathrm{C}\right)$, humidity $(50 \pm 10 \%)$ and light/dark cycles (12/12h), with water and chow ad libitum. All the animals were supplied and maintained at the Laboratory of Experimental Research on Gynecology and Obstetrics. They were mated so as to obtain the newborns utilized in the study. The local Ethics Committee for Animal Experimentation approved of all the experimental procedures in this study, which ensured compliance with the standards established by the Guide for the Care and Use of Laboratory Animals.

\section{Experimental Procedure}

\section{Experimental groups}

At day 0 of life (on the day of birth), 147 female Wistar rats were randomly divided into two experimental groups: 1) Mild diabetes (STZ, $\mathrm{n}=102$ ) - rats receiving the beta-cytotoxic agent streptozotocin (STZ - SIGMA Chemical Company, St. Louis, Millstone - $100 \mathrm{mg} / \mathrm{kg}$, subcutaneously sc.) dissolved in citrate buffer solution (0.1M, pH 6.5); 2) Control ( $\mathrm{n}=45)$ - rats receiving citrate buffer solution (sc.). The female newborns remained with their mothers during the whole breastfeeding period (22 days after the birth) whereas the male newborns were anesthetized and killed (Portha et al. 1974; Tsuji et al. 1988).

\section{Mating period}

In their adult phase (approximately 100 days of life), each four female rats was mated overnight to non-diabetic male rats. The morning in which sperm was found in the vaginal smear was designated gestational day 0 (Damasceno et al. 2008).

\section{Pregnancy period}

At mornings of days $0,7,14$ and 21 of pregnancy, blood samples were obtained from a cut tail tip for non-fasting glycemic determinations (glucose oxidase) using a glucosimeter (One Touch Ultra Johnson and Johnson ${ }^{\circledR}$ ) in the morning. The values were expressed in milligrams by deciliter $(\mathrm{mg} / \mathrm{dL})$. Glycemia below $120 \mathrm{mg} / \mathrm{dL}$ and glycemia between 120 and $300 \mathrm{mg} / \mathrm{dL}$ at day 0 of pregnancy were established as inclusion criteria for the control group and for the mild-diabetes group, respectively. By considering these two glycemic values, 28 rats were included in the control group, and 28 animals were included in the STZ group. 
The females were maintained in the individual cages.

\section{Maternal weight gain during the pregnancy}

In the mornings of days $0,7,14$ and 21 of pregnancy, the dams were weighed for the determination of body weight gain (maternal weight at day 21 and at day 0 of pregnancy).

\section{Evaluation at term of pregnancy}

At day 21 (end of pregnancy), the rats were anesthetized by sodium thiopental (Thiopentax ${ }^{\circledR}$ dose of $80 \mathrm{mg} / \mathrm{kg}$ ). Next, the blood collection was performed for insulin determination and laparotomy so as to proceed to liver removal, processing and analysis of hepatic glycogen storage.

\section{Liver sample processing}

The assay tubes containing liver samples were placed in the water bath at $100^{\circ} \mathrm{C}$ for approximately one hour and then agitated on an electronic agitator for total digestion of hepatic tissue. Subsequently, saturated sodium sulfate $\left(\mathrm{Na}_{2} \mathrm{SO}_{4}\right)$ solution was added, and the final solution was homogenized; ethyl alcohol was added, and the solution was manually agitated by inversion for later centrifugation. After centrifugation, the supernatant was removed, and the pellet was re-suspended in deionized water, and homogenized again. Hepatic glycogen storage was determined according to the technique proposed by Nomura et al. (2005).

\section{Statistical Analysis}

The data were expressed in mean \pm standard error of the mean. Student $t$ test was used to determine the differences existing between the experimental groups. The limit of statistical significance was $5 \%(\mathrm{p}<0.05)$.

\section{RESULTS}

\section{Maternal weight gain and glycemia during pregnancy}

The STZ group showed increased maternal weight during the whole pregnancy. At days $0,7,14$ and 21 of the pregnancy, these rats showed lower weights $(p<0.05)$ as compared to those of controls. Maternal weight gain (day 21 - day 0 of pregnancy) in the STZ group was reduced in relation to that in the control group (Table 1).

In the control group, glycemia was below 120 $\mathrm{mg} / \mathrm{dL}$ during the whole pregnancy. However, statistically significant increase was observed at days 0 and 14 of the pregnancy in the STZ group as compared to the control (Table 1).

Table 1 - Maternal weight gain and glycemia during the pregnancy of rats with mild diabetes (STZ) and nondiabetic rats (control).

\begin{tabular}{lcc}
\hline & Control $(\mathrm{n}=28)$ & STZ $(\mathrm{n}=28)$ \\
\hline Day 0 & \multicolumn{2}{c}{ Maternal weight gain } \\
Day 7 & $284.19 \pm 4.66$ & $260.71 \pm 7.99^{*}$ \\
Day 14 & $305.29 \pm 5.09$ & $278.81 \pm 7.90^{*}$ \\
Day 21 & $330.96 \pm 5.36$ & $303.26 \pm 8.71^{*}$ \\
Maternal weight gain (day 21-0) & $407.22 \pm 6.43$ & $357.86 \pm 11.67^{*}$ \\
\hline \multicolumn{2}{c}{ Maternal glycemia } \\
\hline Day 0 & $123.03 \pm 2.91$ & $97.81 \pm 4.91^{*}$ \\
Day 7 & $105.0 \pm 10.01$ & $132.1 \pm 10.04^{*}$ \\
Day 14 & $102.8 \pm 12.24$ & $106.6 \pm 13.81$ \\
Day 21 & $83.1 \pm 8.03$ & $93.6 \pm 12.93^{*}$ \\
\hline
\end{tabular}

Data presented as mean \pm standard error of the mean.

$* \mathrm{p}<0.05$ - statistically significant difference (Student $\mathrm{t}$ test).

\section{Liver glycogen and insulin storage}

Liver glycogen storage and insulin levels in the group of STZ rats did not show alterations in term pregnancy as compared to those in the group of control rats $(\mathrm{p}>0.05)$ (Table 2). In the control group, of the 28 liver samples, 20 were evaluated, and eight had to be discarded due to technical failure. 
Table 2 - Liver glycogen storage and insulin levels of rats with mild diabetes (STZ) and non-diabetic rats (control).

\begin{tabular}{lcc}
\hline & Control $(\mathrm{n}=20)$ & STZ $(\mathrm{n}=28)$ \\
\hline Liver Glycogen $(\mathrm{mg} / 500 \mathrm{mg}$ of tissue) & $2.00 \pm 0.26$ & $2.67 \pm 0.26$ \\
Insulin (ug/L) & $0.56 \pm 0.50$ & $0.70 \pm 0.49$ \\
\hline
\end{tabular}

Data presented as mean \pm standard error of the mean. $\mathrm{p}>0.05$ - non-significant.

\section{DISCUSSION}

In this study, the group of rats with neonatal streptozotocin-induced diabetes showed weight gain during the whole pregnancy, but the increases observed at each moment of pregnancy were lower than those of the rats in the control group. Apparently the weight gain reduction of STZ rats during pregnancy was related to growth-hormone alterations caused by diabetes induction in the neonatal period. Decompensated Diabetes mellitus in the humans and experimental diabetes in the animals are frequently related with altered body growth (Kanaka-Gantenbein et al. 2003). Takada et al. (2007) observed that the rats with neonatal STZ-induced diabetes developed the classic conditions of diabetes, showing hyperglycemia, hypoinsulinemia and insulin resistance. Low body weight and reduced adipose tissue were also observed in the adult life.

At the beginning of the pregnancy, glycemia in the STZ rats was compatible with mild diabetes, namely, between 120 and $300 \mathrm{mg} / \mathrm{dL}$. These results were compatible with those found by Portha et al. (1979), who were the first to describe the experimental model for mild-intensity diabetes $(100 \leq$ glycemia $\leq 300 \mathrm{mg} / \mathrm{dL})$ in adult life by using STZ in the neonatal period. In agreement with the present results, other studies showed that mild diabetes could be induced by STZ on the animals first day of birth (Portha and Serradas 1991; Sinzato 2009; Saito et al. 2010; Iessi et al. 2010). Additionally, this model could also be performed on the postnatal day 2, on the postnatal day 5 (n5-STZ) (Wang et al. 1996) and on the $2^{\text {nd }}$ and $9^{\text {th }}$ days of life (Ulicná et al. 1999).

Although STZ was neonatally administered, mild hyperglycemia was only attained in the animal adult phase, prior to the mating period (data not shown). Similarly, Bonner-Weir et al. (1981) showed that offspring rats receiving STZ on the postnatal day 2 showed transitory hyperglycemia followed by normal glycemia until the sixth week of life. It was only after this period that those animals developed diabetes, without the presence of ketone bodies, and did not require insulin treatment, concluding that such hyperglycemic rats showed a selective defect in insulin secretion when it was stimulated by glucose. There are other report describing that diabetes induction using STZ during the neonatal period could cause the onset of mild diabetes in the adult phase of these animals (Capobianco et al. 2003). However, Movassat et al. (1997) showed that the rats with neonatally induced diabetes reached adult life being normoglycemic. This was due to the fact that pancreatic $\beta$-cell regeneration occurred between the postnatal days 4 and 7 , which fostered the occurrence of rats with normoglycemia and of others with hyperglycemia, thus confirming our results.

At days 7, 14 and 21 of the pregnancy, the glycemia of STZ rats did not correspond to the glycema of mild diabetes (glycemia higher than $120 \mathrm{mg} / \mathrm{dL}$ ). However, these animals showed glucose intolerance and insulin resistance in the middle of pregnancy, a similar period to that shown by the women with gestational diabetes, thus demonstrating that, in pregnancy, the pancreatic $\beta$-cells developed a sensitive mechanism to respond to glycemic insults (Iessi et al. 2010). Furthermore, other mechanisms that could explain such situation would be $\beta$-cell regeneration during the development of the rats that received STZ in the neonatal period or the occurrence of alterations mediated by hormones, such as placental lactogen, estrogen and progesterone (Triadou et al. 1982). In addition to the insulin and glycemia dosages, this study aimed at analyzing the influence of neonatal STZinduced diabetes on liver glycogen concentrations in at term pregnancy rats. Results showed no alterations in liver glycogen rates for STZ pregnant rats. This could be related to the fact that the glycemic rate lower than $100 \mathrm{mg} / \mathrm{dL}$ at the end of pregnancy was not sufficient to cause the changes in liver glycogen conversion. The presence of insulin stimulates the glycogen synthase enzyme, which is responsible for storing glucose in the form of glycogen in the hepatic 
tissue. Because insulin concentrations did not show differences between the experimental groups, it could be suggested that glycogen storage in the liver from glucose occurred in a similar fashion to that in the control group, as confirmed by the similar hepatic glycogen rates between the groups. This could also be explained by the pancreatic $\beta$-cell regeneration in the neonatal period as observed by Movassat et al. (1997). Insulin is an anabolic hormone that is essential for glucose homeostasis maintenance, cellular differentiation, uptake control, use and storage of cellular nutrients. The important target tissues for glucose homeostasis regulation by insulin are the liver, muscles and adipose tissue. The anabolic actions of insulin include stimulation to the intracellular use and storage of glucose, amino acids and fatty acids, while they inhibit catabolic processes, such as the degradation of lipids, proteins and glycogen (Carvalheira et al. 2002).

In conclusion, streptozotocin administration in the neonatal period of Wistar rats caused mild diabetes in the adult phase of these animals, as confirmed by the the presence of glycemic alterations in the STZ rats, but such alterations were not sufficient to change the insulin levels and, consequently, there is not impairment in the liver glycogen levels at the end of pregnancy.

\section{ACKNOWLEDGMENTS}

The authors are thankful to Fernanda Pereira Lima (assistant technician); Paula Helena Ortiz Lima and Ana Carolina Inhasz Kiss (Post-graduate student) for their technical contribution; to FAPESP (Brazil) for financial support and to the Research Support Group of the Botucatu School of Medicine, São Paulo State University (Unesp) for its contribution with statistical analysis. There are no conflicts of interest in this manuscript.

\section{REFERENCES}

Aerts L, Van Assche FA. Animal evidence for the transgenerational development of diabetes mellitus. Int J Biochem Cell Biol. 2006; 38(5-6): 894-903.

American Diabetes Association - ADA. http://www.diabetes.org; 2010.
Bonner-Weir S, Trent DF, Honey RN, Weir GC. Responses of neonatal rat islets to streptozotocin. Limited B-cell regeneration and hyperglycemia. Diabetes. 1981; 30(1): 64-69.

Calderon IMP, Rudge MVC, Ramos MD, Peraçoli JC. Estudo longitudinal, bioquímico e histoquímico de placentas de ratas diabética - relação com a macrossomia e o retardo de crescimento intra-uterino. Rev Bras Ginecol Obstet. 1999; 21: 91-98.

Capobianco E, Jawerbaum A, White V, Pustovrh C, Sinner D, Gonzalez ET. Elevated levels of endothelin-1 and prostaglandin E2 and their effect on nitric oxide generation in placental tissue from neonatal streptozotocin-induced diabetic rats. Prostaglandins Leukot Essent Fatty Acids. 2003; 68(3): 225-231.

Carvalheira J, Pollak EJ, Quaas RL, Blake RW. An autoregressive repeatability animal model for test-day records in multiple lactations. J Dairy Sci. 2002; 85(8): 2040-2045.

Damasceno DC, Kempinas WG, Volpato GT, Consoni M, Rudge MVC, Paumgartten FJR. Anomalias Congênitas: Estudos Experimentais. Coopmed: Belo Horizonte; 2008.

Hwang JH, Perseghin G, Rothman DL, Cline GW, Magnusson I, Petersen KF, Shulman GI. Impaired net hepatic glycogen synthesis in insulin-dependent diabetic subjects during mixed meal ingestion. A 13C nuclear magnetic resonance spectroscopy study. $J$ Clin Invest. 1995; 95(2): 783-787.

Iessi IL, Bueno A, Sinzato YK, Taylor KN, Rudge MV, Damasceno DC. Evaluation of neonatally-induced mild diabetes in rats: Maternal and fetal repercussions. Diabetol Metab Syndr. 2010; 2(1): 37.

Kanaka-Gantenbein C, Mastorakos G, Chrousos GP. Endocrine-related causes and consequences of intrauterine growth retardation. Ann N Y Acad Sci. 2003; 997: 150-157.

Kasuga M, Ogawa W, Ohara T. Tissue glycogen content and glucose intolerance. J Clin Invest. 2003; 111(9): 1282-1284.

Movassat J, Saulnier C, Portha B. Insulin administration enhances growth of the beta-cell mass in streptozotocin-treated newborn rats. Diabetes. 1997; 46: 1445-1452.

Nomura Y, Okamoto S, Sakamoto M, Feng Z, Nakamura T. Effect of cobalt on the liver glycogen content in the streptozotocin-induced diabetic rats. Mol Cell Biochem. 2005; 277: 127-130.

Portha B, Levacher C, Picon L, Rosselin G. Diabetogenic effect of streptozotocinin on the rat during the perinatal period. Diabetes. 1974; 23(11): 888-895. 
Portha B, Picon L, Rosselin G. Chemical diabetes in the adult rat as the spontaneous evolution of neonatal diabetes. Diabetologia. 1979; 17(6): 371-377.

Portha B, Serradas P. Improvement in glucose-induced insulin secretion in diabetic rats after long-term glicazide treatment: a comparative study using different models of non-insulin-dependent Diabetes mellitus induced by neonatal streptozotocin. Am J Med. 1991; 90(6A): 15S-21S.

Saito FH, Damasceno DC, Kempinas WG, Morceli G, Sinzato YK, Taylor KN, Rudge MV. Repercussions of mild diabetes on pregnancy in Wistar rats and on the fetal development. Diabetol Metab Syndr. 2010; 2(1): 26 .

Sinzato YK. Análise morfológica e imunológica de placenta de ratas com diabete de intensidade moderada [Thesis]. Faculdade de Medicina de Botucatu (SP): Universidade Estadual Paulista; 2009.

Souza MD, Sinzato YK, Lima PH, Calderon IM, Rudge MV, Damasceno DC. Oxidative stress status and lipid profiles of diabetic pregnant rats exposed to cigarette smoke. J Reprod Med. 2010; 20: 547-552.

Takada J, Machado MA, Peres SB, Brito LC, BorgesSilva CN, Costa CE, Fonseca-Alaniz MH, Andreotti S, Lima FB. Neonatal streptozotocin-induced diabetes mellitus: a model of insulin resistance associated with loss of adipose mass. Metabolism. 2007; 56(7): 977-984.
Triadou N, Portha B, Picon L, Rosselin G. Experimental chemical diabetes and pregnancy in the rat. Diabetes. 1982; 31: 75-79.

Tsuji K, Taminato T, Usami M, Ishida H, Kitano N, Fukumoto H, Koh G, Kurose T, Yamada Y, Yano H, et al. Characteristic features of insulin secretion in the streptozotocin-induced NIDDM rat model. Metabolism. 1988; 37: 1040-1044.

Ulicná O, Zlatos L, Holzerová J, Kvaszová E, Cársky J, Gvozdjáková A, Kucharská J, Bada V. The effect of streptozotocin-induced diabetes in the neonatal period on hepatic mitochondrial bioenergetics in adult rats. Bratisl Lek Listy. 1999; 100(1): 5-11.

Wang RN, Bouwens L, Kloppel G. Beta-cell growth in adolescent and adult rats treated with streptozotocin during the neonatal period. Diabetologia. 1996; 39(5): 548-557.

Zaidise I, Artal R, Bessman SP. Metabolismo de combustíveis na gravidez - aspectos teóricos. In: Artal, R., Wiswell, R.A., Drinkwater, B.L. (Editors), O exercício na gravidez. Manole Ltda.; 1999. 31-44.

Received: November 19, 2010; Revised: February 28, 2011; Accepted: December 14, 2011. 